NASA/TM-2012-217732

\title{
Titanium-Water Thermosyphon Gamma Radiation Exposure and Results
}

James L. Sanzi

Sest, Inc., Middleburg Heights, Ohio

Donald A. Jaworske and Debra A. Goodenow

Glenn Research Center, Cleveland, Ohio 


\section{NASA STI Program . . . in Profile}

Since its founding, NASA has been dedicated to the advancement of aeronautics and space science. The NASA Scientific and Technical Information (STI) program plays a key part in helping NASA maintain this important role.

The NASA STI Program operates under the auspices of the Agency Chief Information Officer. It collects, organizes, provides for archiving, and disseminates NASA's STI. The NASA STI program provides access to the NASA Aeronautics and Space Database and its public interface, the NASA Technical Reports Server, thus providing one of the largest collections of aeronautical and space science STI in the world. Results are published in both non-NASA channels and by NASA in the NASA STI Report Series, which includes the following report types:

- TECHNICAL PUBLICATION. Reports of completed research or a major significant phase of research that present the results of NASA programs and include extensive data or theoretical analysis. Includes compilations of significant scientific and technical data and information deemed to be of continuing reference value. NASA counterpart of peer-reviewed formal professional papers but has less stringent limitations on manuscript length and extent of graphic presentations.

- TECHNICAL MEMORANDUM. Scientific and technical findings that are preliminary or of specialized interest, e.g., quick release reports, working papers, and bibliographies that contain minimal annotation. Does not contain extensive analysis.

- CONTRACTOR REPORT. Scientific and technical findings by NASA-sponsored contractors and grantees.
- CONFERENCE PUBLICATION. Collected papers from scientific and technical conferences, symposia, seminars, or other meetings sponsored or cosponsored by NASA.

- SPECIAL PUBLICATION. Scientific, technical, or historical information from NASA programs, projects, and missions, often concerned with subjects having substantial public interest.

- TECHNICAL TRANSLATION. Englishlanguage translations of foreign scientific and technical material pertinent to NASA's mission.

Specialized services also include creating custom thesauri, building customized databases, organizing and publishing research results.

For more information about the NASA STI program, see the following:

- Access the NASA STI program home page at http://www.sti.nasa.gov

- E-mail your question to help@sti.nasa.gov

- Fax your question to the NASA STI Information Desk at 443-757-5803

- Phone the NASA STI Information Desk at 443-757-5802

- Write to: STI Information Desk NASA Center for AeroSpace Information 7115 Standard Drive Hanover, MD 21076-1320 
NASA/TM-2012-217732

AIAA-2012-4078

\section{Titanium-Water Thermosyphon Gamma Radiation Exposure and Results}

James L. Sanzi

Sest, Inc., Middleburg Heights, Ohio

Donald A. Jaworske and Debra A. Goodenow

Glenn Research Center, Cleveland, Ohio

Prepared for the

10th International Energy Conversion Engineering Conference (IECEC)

sponsored by the American Institute of Aeronautics and Astronautics

Atlanta, Georgia, July 30-August 1, 2012

National Aeronautics and

Space Administration

Glenn Research Center

Cleveland, Ohio 44135 


\section{Acknowledgments}

The authors thank Robin Sharpe for his thoughtful preparations at Sandia National Laboratories prior to our visit and for serving as host while at the Gamma Irradiation Facility.

Trade names and trademarks are used in this report for identification only. Their usage does not constitute an official endorsement, either expressed or implied, by the National Aeronautics and Space Administration.

Level of Review: This material has been technically reviewed by technical management.

Available from

NASA Center for Aerospace Information 7115 Standard Drive

Hanover, MD 21076-1320
National Technical Information Service 5301 Shawnee Road Alexandria, VA 22312

Available electronically at http://www.sti.nasa.gov 


\title{
Titanium-Water Thermosyphon Gamma Radiation Exposure and Results
}

\author{
James L. Sanzi \\ Sest, Inc. \\ Middleburg Heights, Ohio 44130 \\ Donald A. Jaworske and Debra A. Goodenow \\ National Aeronautics and Space Administration \\ Glenn Research Center \\ Cleveland, Ohio 44135
}

\begin{abstract}
Titanium-water thermosyphons are being considered for use in heat rejection systems for fission power systems. Their proximity to the nuclear reactor will result in some gamma irradiation.

Noncondensable gas formation from radiation-induced breakdown of water over time may render portions of the thermosyphon condenser inoperable. A series of developmental thermosyphons were operated at nominal operating temperature under accelerated gamma irradiation, with exposures on the same order of magnitude as that expected in 8 years of heat rejection system operation. Temperature data were obtained during exposure at three locations on each thermosyphon: evaporator, condenser, and condenser end cap. Some noncondensable gas was evident; however, thermosyphon performance was not affected because the noncondensable gas was compressed into the fill tube region at the top of the thermosyphon, away from the heat rejecting fin. The trend appeared to be an increasing amount of noncondensable gas formation with increasing gamma irradiation dose. Hydrogen is thought to be the most likely candidate for the noncondensable gas and hydrogen is known to diffuse through grain boundaries. Post-exposure evaluation of one thermosyphon in a vacuum chamber and at temperature revealed that the noncondensable gas diffused out of the thermosyphon over a relatively short period of time. Further research shows a number of experimental and theoretical examples of radiolysis occurring through gamma radiation alone in pure water.
\end{abstract}

\section{Nomenclature}

$\begin{array}{ll}B & \text { total number of atoms diffusing } \\ C(t) & \text { concentration at time } t \\ D & \text { diffusivity } \\ \text { GIF } & \text { Gamma Irradiation Facility } \\ \text { hrs } & \text { hours } \\ \text { MRad (Si) } & \text { million radiation absorbed dose to silicon } \\ \text { TLD } & \text { thermoluminescent detector } \\ t & \text { time } \\ \text { SNL } & \text { Sandia National Laboratories }\end{array}$

\section{Introduction}

Fission power systems are contemplated for the human exploration of the moon and Mars, and an artist's concept is shown in Figure 1. Waste heat will be rejected to the environment utilizing a heat rejection system consisting of heat pipes embedded in a radiator panel (Ref. 1). Titanium-water heat pipes, operating as thermosyphons, will provide the means of spreading heat across the expanse of the 


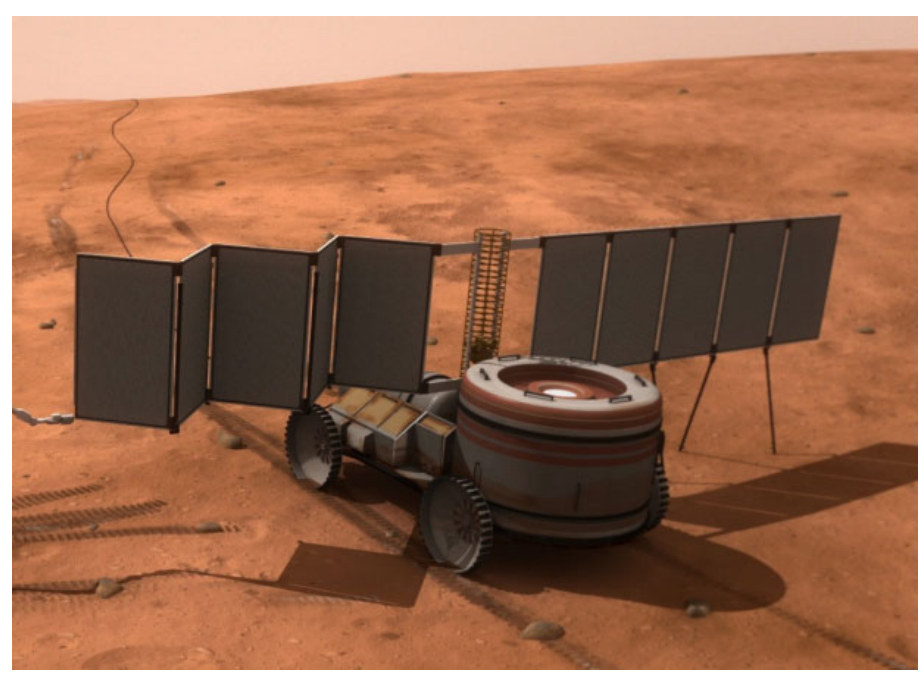

Figure 1.-Artist's concept of a fission power system on Mars.

panel. Though the reactor will be shielded, the thermosyphons in the radiator panel will reside in a gamma radiation environment expected to vary across the span of the panel. Noncondensable gas formation from radiation-induced breakdown of water over time may render portions of the thermosyphon inoperable. Information on radiolysis gleaned from the literature offers differing points of view (Refs. 2 to 6). Radiolysis is guided by energy deposition over a given path length. Hydrogen and hydroxyl radicals are created followed by either the formation of numerous hydrogen and oxygen species, or prompt recombination to form water. One school of thought suggests that the amount of water in the thermosyphons is small resulting in a small path length and prompt recombination, yielding a minimal amount of gas formation (Ref. 3). Another thought suggests that the distribution of fluid and vapor within the operating thermosyphons inhibits recombination, making gas formation from the working fluid in the thermosyphons likely (Ref. 2). The latter was found to be the case here.

Titanium-water heat pipes operating as thermosyphons are being considered for use in heat rejection systems for fission power systems. Their proximity to the nuclear reactor may result in some exposure to gamma radiation. Noncondensable gas formation from radiation-induced breakdown of water over time may render portions of the thermosyphon condenser inoperable. In this test, thermosyphons were operated at temperature under accelerated gamma irradiation, with exposures on the same order of magnitude as that expected in 8 years of actual heat rejection system operation, though this testing was considerably accelerated, occurring in hours. Temperature data were obtained during exposure at three locations on each thermosyphon: evaporator, condenser, and fill tube. Under ideal conditions, the thermosyphon should operate isothermally. A decrease in temperature near the fill tube compared to the evaporator serves as an initial indication of noncondensable gas formation. A second indication is a decrease in temperature at the top of the condenser compared to the evaporator and serves to indicate that the noncondensable gas is beginning to infringe on the working fluid at the condenser. The objective for this testing was to gather temperature data from these three locations on thermosyphons operating at $400 \mathrm{~K}$ in a gamma irradiation exposure environment to reveal the presence and magnitude of noncondensable gas formation and its impact on condenser operation. The testing revealed the formation of a small amount of noncondensable gas in all heat pipes, with those having the greatest dose yielding the greatest amount of noncondensable gas. Though noncondensable gas was evident, thermosyphon performance was not affected because the noncondensable gas was compressed into the fill tube region at the top of the thermosyphon, away from the heat rejecting fins. As an aside, one thermosyphon was heated in vacuum after gamma irradiation in order to drive off the noncondensable gas thereby returning thermosyphon operation to normal. 


\section{Radiolysis}

Radiolysis, in the context of this paper, is the disassociation of water into its constituents of hydrogen and hydroxyl through energy being imparted by incident radiation, commonly neutron or gamma. In this case, the thermosyphons were irradiated only in a gamma radiation field. The gamma fluence values were based on calculations provided by Sandia National Laboratories (SNL). This fluence is based on a projected 8-year lifetime for the fission power system installation (Ref. 1).

Initial research concluded that the amount of water in the thermosyphons would lead to negligible radiolysis as discussed (Ref. 3). It was thought that the gamma radiation would not produce a significant amount of noncondensable gas through radiolysis or that free radicals created would recombine as soon as they were produced. When the thermosyphons were irradiated, however, noncondensable gas formed. The experimental results showed a change in the temperature distribution of the thermosyphons that was not noted during the nonradiation testing, and indicated a buildup of noncondensable gas, presumably hydrogen. The amount of gas created was small but noticeable based on the temperature distribution. Further research also showed a number of documented experimental and theoretical examples of radiolysis occurring only through gamma irradiation of pure water (Refs. 4 and 5).

The amount of radiolysis observed was measured by the delta $\mathrm{T}$ across the length of the thermosyphon, not by volume of gas generated or efficiency degradation of the thermosyphons. Also subsequent testing at NASA Glenn Research Center in a vacuum chamber indicated the hydrogen diffuses out through the titanium and by the end of the test the thermosyphon tested was operating at near preirradiation temperature gradients. The likely reason for the higher-than-expected radiolysis in the thermosyphons could be the fact that much of the water inventory was arranged in a thin film around the inside of the thermosyphon, where the film of water is best modeled as a two-dimensional feature limiting free radical recombination and precluding the bulk of the water from self shielding.

\section{Methods and Materials}

Details of the experiment hardware are reported elsewhere (Ref. 7). In short, the experiment consisted of an electrically heated heater block holding six thermosyphons at a time, and a total of 10 identical titanium-water thermosyphons. Master Bond, Inc., EP30HT-LO epoxy doped with silver powder was used to bond each thermosyphon to Poco graphite foam saddles and graphite fiber-RS-3 isocyanate resin polymer matrix composite fins, installed for cooling. Multiple exposures were obtained through sequential removal and replacement of thermosyphon pairs. The thermosyphons were arranged in a hexagonal pattern, as shown in Figure 2. Radiation-resistant type $\mathrm{K}$ thermocouples were attached to the thermosyphon via band clamps. Three thermocouples were attached to each thermosyphon at the evaporator, condenser, and fill tube. Thermal performance was characterized in air at the operating temperature of $400 \mathrm{~K}$, before, during, and after gamma irradiation exposure. The temperature difference between evaporator and fill tube and between evaporator and condenser revealed the presence or absence of noncondensable gas. A decrease in temperature near the condenser end cap compared to the evaporator serves to indicate that the noncondensable gas is beginning to infringe on the working fluid at the condenser.

\section{Gamma Irradiation Exposure}

Exposure to gamma radiation was achieved at the SNL Gamma Irradiation Facility (GIF). The sequential exposures were as follows: one thermoluminescent detector (TLD) run of $10 \mathrm{~min}$, three sequential exposures of 48, 143, and $286 \mathrm{~min}$, and a second TLD run of $10 \mathrm{~min}$. The first TLD run was for facility documentation and the second TLD run was for calibration. Both of these short exposures were considered negligible in the subsequent total dose calculations. These three exposure times were selected to bracket the expected doses anticipated in lunar operation, though the dose rate was greatly accelerated. At the conclusion of irradiation, all 10 thermosyphons were returned to NASA Glenn Research Center. 


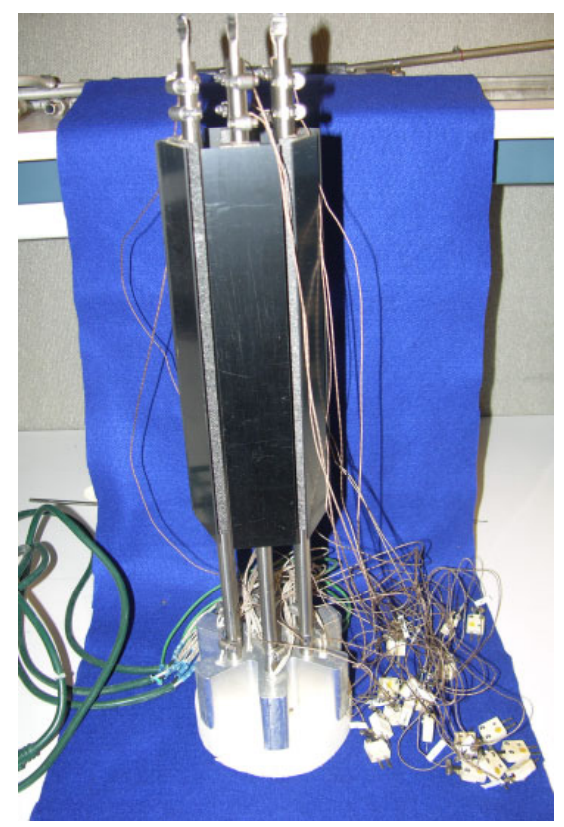

Figure 2.-Thermosyphon test setup.

TABLE 1.-EXPOSURE MATRIX WITH RUN LOCATION AND CALCULATED TOTAL DOSE

\begin{tabular}{|c|c|c|c|c|c|}
\hline Time & TS 5,14 & TS 4,12 & TS 2, 9 & TS 3,8 & TS 15,6 \\
\hline $\begin{array}{l}10 \text { min } \\
\text { (TLD) }\end{array}$ & $\mathrm{X}$ & $\mathrm{X}$ & & & $\mathrm{X}$ \\
\hline $48 \mathrm{~min}$ & $\mathrm{X}$ & $\mathrm{X}$ & & & $\mathrm{X}$ \\
\hline $143 \mathrm{~min}$ & & $\mathrm{X}$ & & $\mathrm{X}$ & $\mathrm{X}$ \\
\hline $286 \min$ & & & $\mathrm{X}$ & $\mathrm{X}$ & $\bar{X}$ \\
\hline $\begin{array}{l}10 \mathrm{~min} \\
\text { (TLD) }\end{array}$ & & & $\mathrm{X}$ & $\mathrm{X}$ & $\mathrm{X}$ \\
\hline Total (min) & $\begin{array}{c}48 \\
\text { (0.3 Mrad dose) }\end{array}$ & $\begin{array}{c}191 \\
\text { (1.3 Mrad dose) }\end{array}$ & $\begin{array}{c}286 \\
\text { (2 Mrad dose) }\end{array}$ & $\begin{array}{c}429 \\
\text { (3.5 Mrad dose) }\end{array}$ & $\begin{array}{c}577 \\
\text { (4.1 Mrad dose) }\end{array}$ \\
\hline
\end{tabular}

\section{Thermoluminescent Detector Calculations}

Total dose was calculated based on location, time, and the counts obtained from the processing of TLDs. In brief, the TLDs were supplied in packs of four, placed at three heights along each thermosyphon, at all six thermosyphon locations, thus supplying a total of 72 TLD readings per calibration run. The average dose per thermosyphon location was found and the average dose per location was multiplied by the time that each thermosyphon was at that location to identify the specific thermosyphon dose. For each titanium-water thermosyphon exposed, the counts for all three heights were averaged and a single dose was calculated and expressed with respect to silicon. Actual values were slightly less than predicted values, with the actual dose ( $\mathrm{Si}$ ) falling in the range of 0.3 to $4.1 \mathrm{MRad}$.

\section{Selected Post-Gamma Irradiation Exposure}

One post-irradiation thermosyphon was placed in a vacuum facility at NASA Glenn Research Center to understand the nature of the noncondensable gas, the idea being that the noncondensable gas composition was primarily hydrogen and that hydrogen is known to diffuse through titanium at elevated temperatures. Chemical recombination of hydrogen and oxygen was not considered. The vacuum facility selected was Vacuum Facility 17 and the thermocouple temperatures were monitored over time. Approximately 1000 hrs were added to the operation of thermosyphon 9. As before, the temperature difference between evaporator and fill tube revealed the retention or loss of noncondensable gas. 


\section{Results and Discussion}

Temperature difference (delta $\mathrm{T}$ ) was used as a measure of noncondensable gas formation in the thermosyphons before, during, and after gamma radiation exposure. A delta T greater than $2 \mathrm{~K}$ served to suggest the presence of noncondensable gas at that thermocouple location. Figure 3 summarizes each delta $\mathrm{T}$ for 9 of 10 thermosyphons and all five exposures, with the temperature difference between evaporator and fill tube ("Evap to Fill”) and the temperature difference between evaporator and condenser ("Evap to Cond") identified. Data from one thermosyphon was spurious due to thermocouple error and was omitted. Small amounts of noncondensable gas that collect only at the top of the thermosyphon do not interfere with condenser operation, being compressed there by the working fluid of the pipe. Larger amounts of noncondensable gas that start to infringe on the finned region of the condenser begin to interfere with thermosyphon heat rejection capacity.

Most thermosyphons exhibited some noncondensable gas formation with the indicator being an evaporator to fill tube temperature difference greater than $2 \mathrm{~K}$, though not enough to begin infringing on condenser operation. The trend appears to be an increasing amount of noncondensable gas formation with increasing gamma irradiation dose. The evaporator to condenser data indicate all of the thermosyphons have fully functional condensers with the fins being unaffected by the noncondensable gas, as all have an evaporator to condenser temperature difference less than or equal to $2 \mathrm{~K}$.

Post-exposure evaluation of one thermosyphon operating continuously under vacuum at $400 \mathrm{~K}$ revealed that the noncondensable gas diffused out of the thermosyphon over a matter of several hundred hours. Fick's second law of diffusion was used as a model to approximate the diffusion of a finite number of atoms from a fixed enclosure.

Equation (1) summarizes the relevant function from a finite source of atoms, that is, the interior of the thermosyphon:

$$
C(t)=B /(\pi D t)^{0.5}
$$

where concentration in the source, $C$, at a given time $(t)$ is a function of the total number of atoms diffusing, $B$, the diffusivity of the atoms, $D$, and time, $t$. Though the number of atoms is not specifically known, a plot of the value of delta $\mathrm{T}$ from the thermocouples measuring evaporator and fill tube temperatures, and the inverse of the square root of time should provide a linear function, passing through zero at infinite time. The data from thermosyphon 9 are presented in this fashion in Figure 4.

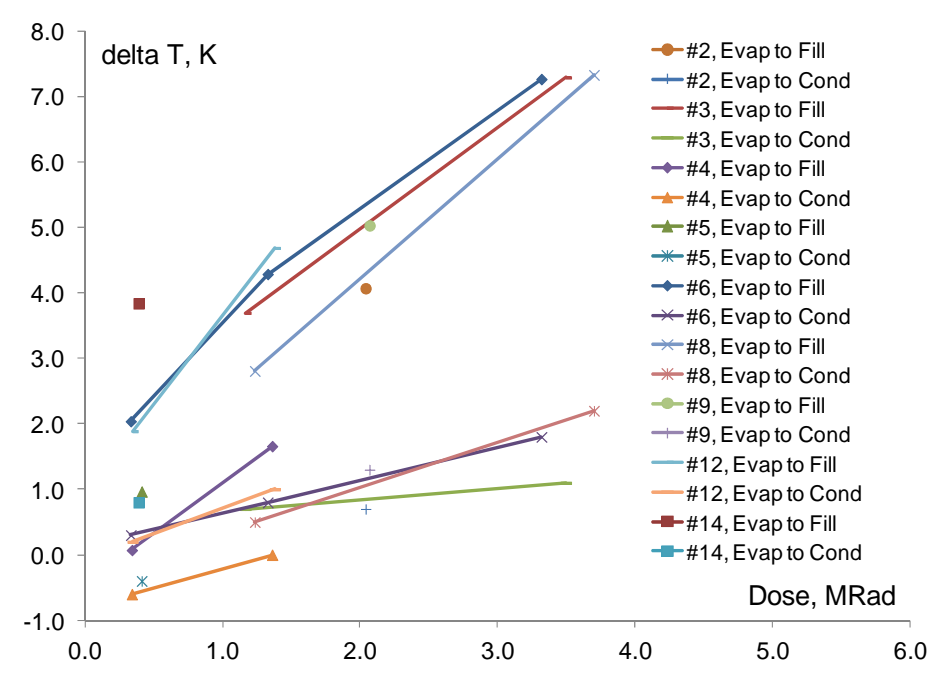

Figure 3.-Delta T versus dose (Si). 


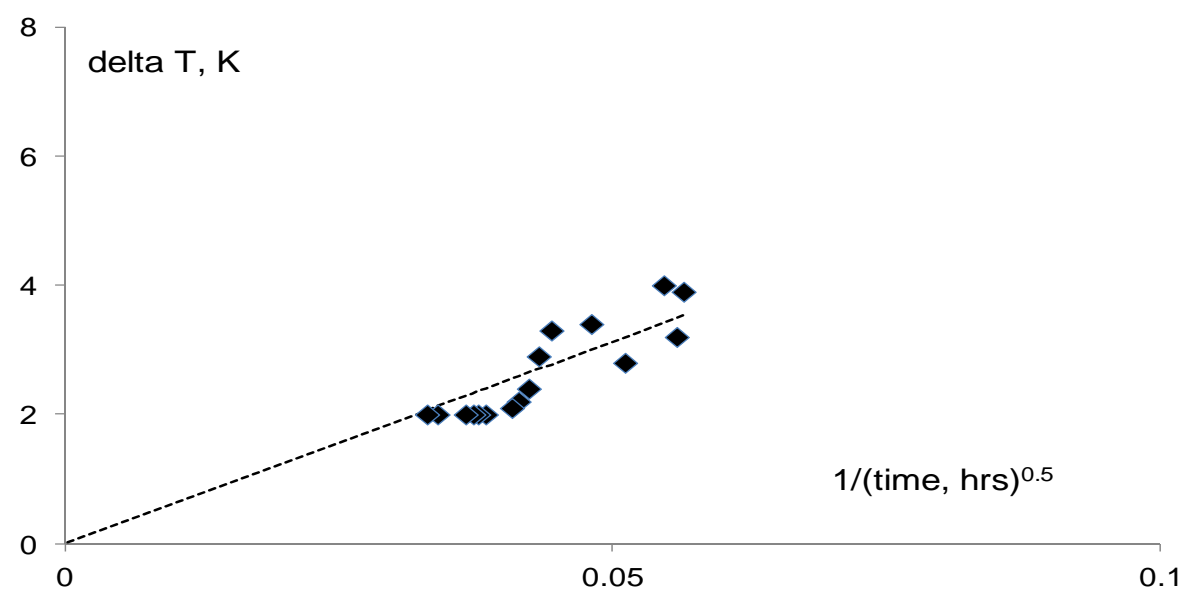

Figure 4.-Delta T versus an inverse function of time, under vacuum at $400 \mathrm{~K}$.

\section{Conclusions}

The heat rejection system is an important part of a fission surface power system envisioned for use on the moon or Mars. To generate $40 \mathrm{kw}_{\mathrm{e}}$, approximately $140 \mathrm{~kW}_{\mathrm{t}}$ of waste heat will need to be rejected, according to one reference concept. Spreading the heat across the expanse of a radiator panel is envisioned to occur through the use of titanium-water heat pipes operating as thermosyphons. Even with shielding around the reactor, there may be some gamma radiation impinging on the water in the thermosyphons serving as the working fluid. A number of thermosyphons operating at temperature were exposed to a gamma radiation source at the Gamma Irradiation Facility at Sandia National Laboratories to understand the impact of gamma irradiation on thermosyphon operation. Though a small amount of hydrogen was generated from the radiolysis of the water, increasing with increasing dose, results from subsequent vacuum testing on the diffusion of hydrogen through the titanium vessel were modeled utilizing Fick's second law of diffusion and it was found that diffusion at temperature was rapid compared to the generation of hydrogen over the anticipated lifetime of the system. Hence, accumulation of hydrogen inside the operating thermosyphons is not expected.

\section{References}

1. Mason, L., "Recent Advances in Power Conversion and Heat Rejection Technology for Fission Surface Power," Proceedings of Nuclear and Emerging Technologies for Space 2009, American Nuclear Society, Atlanta, GA, 2009, paper 204298.

2. Vinson, D.W., Deible, R.W., and Sindelar, R.L., "Evaluation of Hydrogen Generation from Radiolysis from Breached Spent Fuel,” Westinghouse Savannah River Company, WSRC-MS-200200728, Savannah River Site, Aiken, SC, 2002.

3. Hart, E.J., McDonell, W.R., and Gordon, S., "The Decomposition of Light and Heavy Water Boric Acid Solutions by Nuclear Reactor Radiations,” Proceedings of the International Conference on the Peaceful Uses of Atomic Energy, Geneva 1955, P/839, Vol. 7, United Nations, New York, NY, 1956, pp. 593-598.

4. Bjergbakke, E., Draganic, Z.D., Sehested, K., and Draganic, I.G., "Radiolytic Products in Waters Part I: Computer Simulation of Some Radiolytic Processes in the Laboratory,” Radiochemica Acta, Vol. 48, 1989, pp. 65-71. 
5. Loyd, J.A., Eller, P.G., and Hyder, L., "Literature Search on Hydrogen/Oxygen Recombination and Generation in Plutonium Storage Environments,” Los Alamos National Laboratory, LA-UR-984557, Los Alamos, NM, 1998.

6. LaVerne, J.A., "OH Radicals and Oxidizing Products in the Gamma Radiolysis of Water," Radiation Research Society, Vol. 153, No. 2, Feb. 2000, pp. 196-200.

7. Sanzi, J.L., and Jaworske, D.A., "Titanium-Water Thermosyphon Gamma Radiation Effects," Nuclear and Emerging Technologies for Space 2012, American Nuclear Society, The Woodlands, TX, 2012, paper 3055. 


\begin{tabular}{|c|c|c|}
\hline \multicolumn{2}{|c|}{ REPORT DOCUMENTATION PAGE } & $\begin{array}{l}\text { Form Approved } \\
\text { OMB No. 0704-0188 }\end{array}$ \\
\hline \multicolumn{3}{|c|}{ 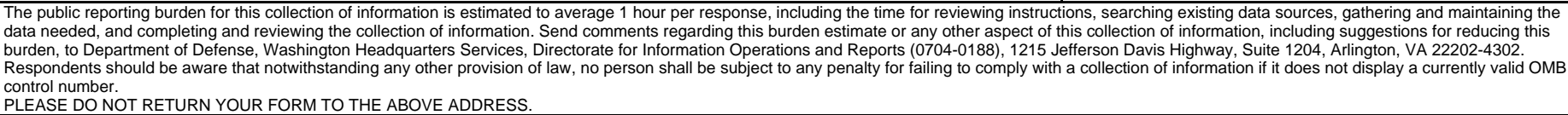 } \\
\hline $\begin{array}{l}\text { 1. REPORT DATE (DD-MM-YYYY) } \\
01-09-2012\end{array}$ & $\begin{array}{l}\text { 2. REPORT TYPE } \\
\text { Technical Memorandum }\end{array}$ & 3. DATES COVERED (From - To) \\
\hline \multirow{3}{*}{\multicolumn{2}{|c|}{$\begin{array}{l}\text { 4. TITLE AND SUBTITLE } \\
\text { Titanium-Water Thermosyphon Gamma Radiation Exposure and R }\end{array}$}} & 5a. CONTRACT NUMBER \\
\hline & & 5b. GRANT NUMBER \\
\hline & & 5c. PROGRAM ELEMENT NUMBER \\
\hline \multirow{3}{*}{\multicolumn{2}{|c|}{$\begin{array}{l}\text { 6. AUTHOR(S) } \\
\text { Sanzi, James, L.; Jaworske, Donald, A.; Goodenow, Debra, A. }\end{array}$}} & 5d. PROJECT NUMBER \\
\hline & & 5e. TASK NUMBER \\
\hline & & $\begin{array}{l}\text { 5f. WORK UNIT NUMBER } \\
\text { WBS } 887359.01 .04\end{array}$ \\
\hline \multicolumn{2}{|c|}{$\begin{array}{l}\text { 7. PERFORMING ORGANIZATION NAME(S) AND ADDRESS(ES) } \\
\text { National Aeronautics and Space Administration } \\
\text { John H. Glenn Research Center at Lewis Field } \\
\text { Cleveland, Ohio 44135-3191 }\end{array}$} & $\begin{array}{l}\text { 8. PERFORMING ORGANIZATION } \\
\text { REPORT NUMBER } \\
\text { E-18229 }\end{array}$ \\
\hline \multirow{2}{*}{\multicolumn{2}{|c|}{$\begin{array}{l}\text { 9. SPONSORING/MONITORING AGENCY NAME(S) AND ADDRESS(ES) } \\
\text { National Aeronautics and Space Administration } \\
\text { Washington, DC 20546-0001 }\end{array}$}} & $\begin{array}{l}\text { 10. SPONSORING/MONITOR'S } \\
\text { ACRONYM(S) } \\
\text { NASA }\end{array}$ \\
\hline & & $\begin{array}{l}\text { 11. SPONSORING/MONITORING } \\
\text { REPORT NUMBER } \\
\text { NASA/TM-2012-217732 }\end{array}$ \\
\hline \multicolumn{3}{|c|}{$\begin{array}{l}\text { 12. DISTRIBUTION/AVAILABILITY STATEMENT } \\
\text { Unclassified-Unlimited } \\
\text { Subject Category: } 20 \\
\text { Available electronically at http://www.sti.nasa.gov } \\
\text { This publication is available from the NASA Center for AeroSpace Information, 443-757-5802 }\end{array}$} \\
\hline
\end{tabular}

\section{SUPPLEMENTARY NOTES}

\section{ABSTRACT}

Titanium-water thermosyphons are being considered for use in heat rejection systems for fission power systems. Their proximity to the nuclear reactor will result in some gamma irradiation. Noncondensable gas formation from radiation-induced breakdown of water over time may render portions of the thermosyphon condenser inoperable. A series of developmental thermosyphons were operated at nominal operating temperature under accelerated gamma irradiation, with exposures on the same order of magnitude as that expected in 8 years of heat rejection system operation. Temperature data were obtained during exposure at three locations on each thermosyphon: evaporator, condenser, and condenser end cap. Some noncondensable gas was evident; however, thermosyphon performance was not affected because the noncondensable gas was compressed into the fill tube region at the top of the thermosyphon, away from the heat rejecting fin. The trend appeared to be an increasing amount of noncondensable gas formation with increasing gamma irradiation dose. Hydrogen is thought to be the most likely candidate for the noncondensable gas and hydrogen is known to diffuse through grain boundaries. Post-exposure evaluation of one thermosyphon in a vacuum chamber and at temperature revealed that the noncondensable gas diffused out of the thermosyphon over a relatively short period of time. Further research shows a number of experimental and theoretical examples of radiolysis occurring through gamma radiation alone in pure water.

15. SUBJECT TERMS

Heat pipes; Thermosyphons; Gamma radiation; Radiators

\begin{tabular}{|c|c|c|c|c|c|}
\hline \multicolumn{3}{|c|}{ 16. SECURITY CLASSIFICATION OF: } & \multirow{2}{*}{$\begin{array}{l}\text { 17. LIMITATION OF } \\
\text { ABSTRACT } \\
\text { UU }\end{array}$} & \multirow{2}{*}{$\begin{array}{l}\text { 18. NUMBER } \\
\text { OF } \\
\text { PAGES } \\
14\end{array}$} & \multirow{2}{*}{$\begin{array}{l}\text { 19a. NAME OF RESPONSIBLE PERSON } \\
\text { STI Help Desk (email:help@sti.nasa.gov) } \\
\text { 19b. TELEPHONE NUMBER (include area code) } \\
\text { 443-757-5802 }\end{array}$} \\
\hline $\begin{array}{l}\text { a. REPORT } \\
\text { U }\end{array}$ & $\begin{array}{l}\text { b. ABSTRACT } \\
\text { U }\end{array}$ & $\begin{array}{l}\text { c. THIS } \\
\text { PAGE } \\
\text { U }\end{array}$ & & & \\
\hline
\end{tabular}



